\title{
РОЛЬ МУЗИЧНОЇ ОСВІТИ І МУЗИЧНОГО МИСТЕЦТВА В ПОГЛИБЛЕННІ ВМІНЬ І НАВИЧОК СПРИЙНЯТТЯ МУЗИКИ У СТУДЕНТІВ-ХОРЕОГРАФІВ
}

Vybrana liryka i proza [The unspoken songs. The selected lyric poetry and prose]. Niu-York: Burlaky, 93 p. [in Ukrainian].

5. Kupchynskyi, R. (1916). Dva braty (pamiaty nezabutnoho tovarysha Romualda Lutsyka) [Two brothers (memory unforgettable comrade Romualda Lucika)]. Shliakhy, vol. 6, p. 84. [in Ukrainian].

6. Lenyk, V. (1994). Ukrainska orhanizovana molod (molodechi orhanizatsii do 1914 r.) [Ukrainian organized youth (youth organization to 1914)]. Miunkhen; Lviv: Feniks LTD, p. 50. [in Ukrainian].

7.Myydemo vbii: Povnyizbirnykpisen R. Kupchynskoho (1977). [Wego intobattle: the complete collection of songs by R. Kupchynskij]. (Ed.). I. Sonevytskyi. Niu-York: Chervona kalyna, p. 130. [in Ukrainian].

8. Surma: zbirnyk voiennykh pisen (1922). [Trumpet: collection of war songs]. Kyiv-Lviv, p. 2. [in Ukrainian].

Стаття надійшла до редакції 13.02.2018

УДК 378.147:792.8

DOI:

Ірина Горчинська, провідний концертмейстер кафедри народної хореографії Київський національний університет культури і мистецтв

\section{РОЛЬ МУЗИЧНОЇ ОСВІТИ І МУЗИЧНОГО МИСТЕЦТВА В ПОГЛИБЛЕННІ ВМІНЬ І НАВИЧОК СПРИЙНЯТТЯ МУЗИКИ У СТУДЕНТІВ-ХОРЕОГРАФІВ}

Основною формою навчально-виховного процесу у студентів-хореографів є урок музичного мистецтвва, який поєднує в собі: музичне навчання, музичне виховання і музичний розвиток студентів-хореографів. Метою $i$ змістом музичної освіти є формування музичної культури особистості, щуо передбачає виховання $і$ самовиховання музичного та естетичного внутрішнього світу студента-хореографа. Інструментом засвоєння знань, формування вмінь і навичок є методи і принципи музичного навчання. Вони передбачають взаємодію вчителяхореографа, концертмейстера та студента у процесі художньо-естетичного спілкування на уроці музичного мистецтва. Метою і змістом музичної освіти є формування музичної культури студента, шуо передбачає виховання його музичного і естетичного внутрішнього світу на лекціях і уроках музичного мистецтва.

Ключові слова: музична освіта, мета і зміст навчання, сприйняття музики студентами-хореографами. Лim. 8.

Iryna Horchynska, Lead Concertmaster of the Folk and Classical Choreography Department Kyiv National University of Culture and Arts

\section{THE ROLE OF MUSICAL EDUCATION IN DEE PENING THE SKILLS OF MUSIC PERCEPTION AMONG THE STUDENTS-CHOREOGRAPHERS}

The main form of the educational process for a student of choreography is a musical art lesson, which combines musical training, musical education and musical development of the students of choreography. The purpose and content of musical education is the formation of musical culture of an individual, which involves the education and self-education of the musical and aesthetic inner world of the students of choreography. The tool for assimilating knowledge and the formation of skills is the methods and principles of musical training. They provide for the interaction of a teacher of choreography, a concertmaster and a student in the process of artistic and aesthetic communication at the musical art lesson. The purpose and content of musical education is the formation of the student's musical culture, which involves the formation of musical and aesthetic inner world during lectures and music art lessons. These include explanation, narration, conversation, illustration of works of musical art, observation of the development of work of the student-selected musical composition or dance, studying the emotional influence of the musical work. This is the whole process of learning the basics of musical art, assimilating knowledge, skills and abilities in specific types of musical activities. A student of choreography acquires musical training, musical education and musical development in the field of musical art. The basis and purpose of musical education at music art lessons is the formation of ideas about the nature, types and genres of musical art in the process of familiarizing with classical, folk and modern music, the interpretation of its content, intonational image-bearing language of the work, with the dance or composition created on its basis. It is very important to achieve the musical literacy of a student in the process of training during the lessons of Theory of Music. The assimilation of musical notions and musical terminology is necessary for the perception, comprehension and interpretation of works of musical art.

Keywords: musical education, the purpose and content of training, perception of music by students-choreographers.

остановка проблеми. Одне із завдань музичної освіти і музичного мистецтва розвиток музично-творчих здібностей і самовиявлення в ритмічній та пластичній імпровізації, уяві й фантазії, розвитку художньо-образного мислення і втілення всіх цих 


\section{РОЛЬ МУЗИЧНОЇ ОСВІТИ І МУЗИЧНОГО МИСТЕЦТВА В ПОГЛИБЛЕННІ ВМІНЬ І НАВИЧОК СПРИЙНЯТТЯ МУЗИКИ У СТУДЕНТІВ-ХОРЕОГРАФІВ}

задач і процесів у створенні хореографічного номеру або танцю. На сучасному етапі відбувається переосмислення й модернізація змісту музичної освіти хореографа. Дедалі більше уваги приділяється запровадженню авторських програм, спрямованих на розвиток індивідуальних творчих здібностей студентів, які використовують Інтернет-ресурси та комп'ютерне навчання, як складові сучасних музично-педагогічних технологій.

Аналіз основних досліджень і публікацій. Питанням розвитку навчально-виховного процесу у студентів-хореографів, який поєднує в собі: музичне навчання, музичне виховання, слухове сприйняття музичного твору, присвячено багато досліджень вітчизняних педагогів, серед них: Г.М.Падалка, А.С. Згурський [1], О.П. Рудницька [7], О.М. Отич [5], В.Ф. Черкасов [8]. Дослідженню ролі сприйняття музики в поглибленні вмінь і навичок студентамихореографами присвячені труди таких вітчизняних педагогів і дослідників як: А.І. Гуменюк, С.О. Зайцев, В.С. Костровицька, Ю.О. Станішевський, Ю.П. Слонімський,К.Є. Василенко, В.М. Верховинець.

Формування мети статті. У професійному навчанні студентів дуже важливе питання стає про необхідність існування зв'язку між музичним твором і хореографією. Необхідність такого зв'язку визнана усіма професійними викладачами, як одна 3 головних задач успішного розвитку музичнотворчих здібностей, вмінь і навичок сприйняття музики студентами.

Справжній виконавець, який удосконалює свої мистецтво, не може не надавати особливого значення розвитку техніки руху й артистичності виконання. При цьому у виконавця повинна бути єдність між музичною та хореографічною фразеологією, або нюансуванням танцю i танцювальних вправ, яка притаманна формам музичного мистецтва.

Звичайно крім знань 3 музичного мистецтва, а сюди входять предмети “Музика”, “Теорія музики”, “Загальне фортепіано”, навчання студента вимагає знання граматики хореографічного мистецтва, якою $є$ “Основи класичного танцю” [2]. Виконавець, який нехтує музичною освітою ніколи не стане професійно підготовленим хореографом-виконавцем. Тому без основ і знань музичної освіти та музичного мистецтва не можна досягти вершин хореографічної майстерності, і розвинути свій природний талант.

Виклад основного матеріалу дослідження 3 повним обгрунтуванням отриманих наукових результатів. Зі здобуттям Україною незалежності 3'явились передумови для формування концепції мистецької освіти, яка охоплює музичну, художню, театральну, хореографічну освіту. Освітні музично-навчальні програми 3 предметів "Музика", “Теорія музики”, "Музичне мистецтво" передбачають такі програмні знання у студентівхореографів:

- художньо-естетичне сприймання музики українських i зарубіжних композиторів, обговорення змісту творів під час дискусій;

- формування умінь і навичок гри на музичних інструментах;

- набуття навичок імпровізації, застосування музики як засобу комунікації та творчого самовираження особистості;

- засвоєння основних музичних понять, усвідомлення особливостей музичної мови.

Все це надає студентам-хореографам можливість ознайомлення з музикою твору, що передає почуття людей, їхні переживання від взаємодії з навколишнім світом. Вони сприймають зміст і характер музичного твору, усвідомлюють специфіку високих і низьких, довгих і коротких музичних звуків, розпізнають в музиці різні настрої, почуття, образи.

Студенти наділені від природи музичним слухом, ніколи не порушують мелодію музичного твору, і як головне, темпоритм мелодії не сковує їх виконавчу ініціативу, не перешкоджає виявленню творчої індивідуальність у постановці хореографічного номеру. Музичне виконання вправ, танців полягає не тільки у коректному мелодійному та темпоритмічному їх сприйнятті, а й в усвідомленні обгрунтованих фундаментальних законів музичного мистецтва, його мелодійної, поліфонічної та динамічної логіки. Тому тільки при оволодінні цими законами та при достатній музичності кожен виконавець буде вільно та легко виконувати хореографічні вправи та танець, постановчі номери в цілому, не порушуючи при цьому музичну та хореографічну структуру вправи, танцю i навпаки, буде з легкістю та вдумливістю виявляти їх ідейно-емоційний зміст.

Варто також зазначити, що справжня музичність може бути розвинута лише за наявності музичної обдарованості і щоденній праці, тому для досягнення цього потрібне послідовне засвоєння знань, які відносяться до теорії та естетики музичного мистецтва у поєднанні їх із засвоєнням, техніки та навичок у хореографічній професії. Все це в однаковій мірі стосується в підготовці викладачів та студентів-хореографів.

На уроках "Музичного мистецтва" вчительхореограф i концертмейстер розкривають 


\section{РОЛЬ МУЗИЧНОЇ ОСВІТИ І МУЗИЧНОГО МИСТЕЦТВА В ПОГЛИБЛЕННІ ВМІНЬ І НАВИЧОК СПРИЙНЯТТЯ МУЗИКИ У СТУДЕНТІВ-ХОРЕОГРАФІВ}

студентами суть таких музичних явищ, як мелодія, пісня, танець, колискова, марш, щедрівка. Студенти мають розрізняти стилі і форми музичних творів, зміст музики цих творів, спостерігати за вираженням композиторами краси, природи та казкових образів своїх творів. Дуже важливо студентам знати про роль композитора, який співпереживає, виявляє почуття й стани розкриті у своїх творах.

На уроках "Музичне мистецтво” i “Теорія музики” студенти з'ясовують способи розвитку музики (виконавські, жанрові, динамічні, мелодичні, темпові), дізнаються про виконавський, жанровий та ладовий розвиток музики, прийоми симфонічного розвитку, 3 обрядами та піснями-веснянками. Студенти одержують знання про одночастинну, двочастинну та тричастинну форми, рондо, варіації та куплетну форму. Дізнаються, що найважливішими принципами будови музики $є$ повторювання і контраст.

Студенти обов'язково на уроках ознайомлюються 3 оперою, балетом, симфонією і інструментальним концертом. На уроках “Загального фортепіано" дуже важливе оволодіння студентамихореографами навичок гри на фортепіано або на інших інструментах для розвитку універсальних творчих якостей, потреби в художньо-творчій самореалізації та духовно-естетичному самовдосконаленні [4].

Вони пізнають музичну мову як виразник образного змісту твору, дізнаються про зв'язок музики з іншими видами мистецтва в опері та балеті. Їх увага зосереджується на вирішальному значенні та особливостях різних елементів музичної мови і мелодії, ритму, метру, ладу, темпу, тембру, динаміки, регістру.

Концертмейстер розповідає, що мелодія у всіх музичних творах є головним засобом виразності, в якій частково визначаються два основні елементи: ритм та інтонація. Отже, сама природа мелодії така, що вона не може існувати без ритму та інтонації, які складають нерозривну єдність. Студенти засвоюють, що мелодія поділяється на окремі мелодичні частини, які називаються мотивами. У свою чергу, кожний мотив має свою кульмінацію.

Студенти визначають роль мелодії і супроводу в музичних творах, здобувають досвід відчуття танцювальності в інструментальних творах. Вони вивчають будову музичного твору, порівнюють і вивчають музичну мову народної музики і музики професійних композиторів.

Вчитель розповідає про те, що пісенність, танцювальність як особливі якості музики пов'язані з піснею і танцем. Студенти-хореографи повинні характеризувати кожний жанр музики і поєднувати їх в музичних творах (пісня-танець, танець) використовуючи в своїх сюжетнопостановчих номерах. Студенти-хореографи обов'язково знайомляться з темою “Інтонація”, в якій вони виявляють спільність розмовної та музичної мов (посилення і послаблення звучання, чергування сильних і слабких долей, смислові наголоси, паузи).

Також у вивченні хореографічного та музичного мистецтва мають дуже важливе значення знання музичної граматики, особливо знання мелодії твору, їі фразеології, яка $є$ фрагментами музичної “мови” (речення). Ці знання дають можливість набути і розширити професійну хореографічну освіту і дають змогу виконавцям-хореографам правильно, музично, художньо виконувати будь-які рухи в танці і весь танець в цілому.

На прикладах хореографічних, музичносценічних жанрів студенти знайомляться 3 близькими за характером образами музичних та літературних творів, порівнюючи образну мову музики з мовою літератури. Важливо щоб студенти спостерігали, як за допомогою музики змінюється емоційний стан людини, формується світогляд, як у музиці виявляються життєві ситуації і якими засобами виразності композитор зображує події [3; 6].

Студенти-хореографи повинні уважно вивчати палітру музичних образів, відтворену в творах сучасних та зарубіжних композиторів, повинні дуже добре знати інтонаційно-образний зміст музичного твору, аналізувати драматургію різних за жанрами та формами музичних композицій, повинні вміти порівнювати музичні образи, визначати композицію музичного твору, основні типи музичної драматургії.

Дуже важливе використання таких музичнопедагогічних технологій, як слухання, інтерпретація інтонаційно-образного змісту музичних творів, імпровізація, пластичне інтонування музичного твору вибраного для постановки і показу. Головну роль у змісті і меті сприймання творів музичного мистецтва відіграє сприймання музики українських та зарубіжних композиторів класичної, народної та сучасної музики.

Сприймання музики відбувається в процесі слухання музики. Також пізнання творів музичного мистецтва відбувається за допомогою відчуттів, а відчуття і сприймання дають цілісне уявлення про зміст музичного твору, що і $\epsilon$ основними формами чуттєвого пізнання. 
В цьому процесі велике значення має виховання музичного слуху. Викладач i концертмейстер мають не забувати, що поряд 3 розвитком слуху одночасно виховується і музичний смак.

Процес сприймання творів музичного мистецтва відбувається у взаємозв'язку з іншими психічними процесами: мисленням, волею, мовою, почуттями, відчуттями, уявою і увагою. На процес сприймання впливають попередні знання та попередній досвід у галузі інтерпретації творів музичного мистецтва, а також рівень розвитку індивідуальних музичних здібностей. При спілкуванні з різними жанрами музики студенти-хореографи розвивають слухове, образне сприймання твору.

Слухаючи твір, який вони вибирають для постановки танцю чи сюжетно-хореографічного номеру, вони визначають особливості мелодії, виразні характеристики штрихів, ритмічних малюнків, гнучкість динаміки і особливості побудови музичного твору. Це об'єктивні умови сприймання. Вони зумовлені особливостями творчого стилю композитора та індивідуальністю виконавця музичного твору чи постановника танцю.

Вдало підібрані музичні твори забезпечують виразне виконання хореографічних рухів (вправ) чи постановчої роботи студента. Від концертмейстера вимагається художнє виконання музичного твору. Викладач-хореограф та концертмейстер не повинні забувати про тісний зв'язок між музикою і танцем, про мелодійний вплив музики на емоційний стан виконавця. Звертати увагу на якість музичного супроводу, бо творчий успіх виконання залежить від музичного змісту, темпоритму, динаміки твору.

Під впливом музики у студентів на уроках музичного мистецтва розвивається емоційне та художньо-естетичне сприймання, що впливає на формування інтелектуальної сфери особистості. Цілеспрямоване сприймання музичного твору передбачає, як цілісне так і поетапне ознайомлення студентів-хореографів 3 його змістом та інтонаційно-образними характеристиками.

Кожен викладач-хореограф має пам'ятати, що музичні твори допомагають підняти та утримувати відповідний емоційний настрій виконавця. Для цього викладач і концертмейстер вибирають виразні та доступні музичні твори, які привчають студентів не тільки слухати музику, а й вживатися в музичний образ, розуміти та відчувати ритмічні та динамічні акценти, фрази, мелодійні відтінки, характер музичного твору, що допомагає виховувати артистичність виконання твору чи вправи.
Процес слухання музичного твору охоплює: вступне слово викладача-хореографа та концертмейстера, слухання твору, його аналіз, бесіду про твір, повторне слухання. Дуже важливо зосереджувати увагу студентів-хореографів на авторах музичних та літературних творів, їній творчості, з'ясуванні жанру твору, а також особливостей епохи, в яку написано або якій присвячено музичний твір, історії створення або передумов, що спонукали композитора до його написання.

Студенти-хореографи повинні прослуховувати музику до твору в “живому” виконанні чи в вигляді запису, застосовуючи сучасні технічні засоби навчання. Емоційні переживання сприяють піднесенню або пригніченню внутрішнього стану і збагачують інтелектуальну складову особистості студента-хореографа. Інтерпретація твору розкриття інтонаційно-образного змісту музичного твору за допомогою емоційно-образних визначень відповідно до мети й завдань поставлених композитором.

Музичний твір допомагає відтворювати певний емоційний настрій та характер руху, наприклад, веселий, енергійний, радісний, жвавий, бадьорий. Ці музичні характеристики вимагають від виконавця і відповідного характеру виконання: чіткий ритм, енергійний характер, а повільні, ліричні чи героїчні твори потребують спокійного, величавого характеру (трохи монотонного темпоритму).

Висновки. Для інтерпретації інтонаційнообразного змісту музичного твору необхідно володіти знаннями в галузі теорії та історії музики. Ці два предмети обов'язково повинні бути опановані студентами-хореографами в процесі навчання.

Під час інтерпретації інтонаційно-образного змісту музичного твору виникають дискусійні ситуації, коли студенти висловлюють різні погляди на виконання твору зі своєї постановки. Студентам пропонуються висловлення власного відчуття розвитку музичної дії, сюжету, обгрунтування асоціативних уявлень, які виникають під час аналізу та зіставлення музичних явищ 3 аналогами образотворчого музичного мистецтва.

Обговорення музичних творів і їх втілення в творчі постановки сприяють розвитку музичної культури студентів, формуванню їхніх ціннісних орієнтацій, надихаючи до подальшого спілкування 3 творами музичного мистецтва, розширюючи кругозір і світосприймання. Варто ще раз підкреслити, що музичне мистецтво, як певна дисципліна, має грунтуватися на основі музичних 
творів, їх мелодійності, гармонійності, поліфонічності та динамічній логіці.

Музика як один з видів мистецтва всебічно виховує виконавця, студента, пробуджує благородні та патріотичні почуття, підвищує їхній естетичний та культурний рівень. Саме завдяки музичній освіті у студентів-хореографів формуються вміння і навички сприйняття музики і музичного мистецтва.

\section{ЛІТЕРАТУРА}

1. Згурський А. С. Танець як засіб виховання пластичної майстерності: навч.-метод. посіб. / А. С. Згурський. - К.: КДУТКіТ ім. І. К. КарпенкаКарого, 2006. - 168 с.

2. Масол Л. М. Загальна мистецька освіта. Теорія і практика: монографія / Л. М. Масол. К.: Промінь, 2006. - 432 с.

3. Михайличенко О. В. Основи загальної та музичної педагогіки. Теорія та історія: навч. посіб. для студентівмузичнихспеціальностей/О.В.Михайличенко. - Суми: Наука, 2004. - 210 с.

4. Олексюк О. М. Музична педагогіка: навч. посіб. / О. М. Олексюк. - К.: КНУКіМ, 2006. $188 \mathrm{c}$.

5. Отич О. М. Мистецтво розвитку індивідуальності педагога. Історичний і методологічний аспект: монографія / О. М. Отич. - Чернівці: Зелена буковина, 2008. - 440 с.

6. Падалка Г. М. Педагогіка. Теорія і методика викладання мистецьких дисциплін / Г. М. Падалка. - К.: Освіта України, 2008. - 274 с.

7. Рудницька О. П. Педагогіка: загальна та мистецька / О. П. Рудницька. - Тернопіль: Навчальна книга, 2005. - 284 с.

8. Черкасов В. Ф. Теорія і методика музичної освіти: навч. посіб. / В. Ф. Черкасов // Серія “Альма-матер”. - К.: ВЦ “Академія”, 2016. - 240 с.

\section{REFERENCES}

1. Zgurskyi, A.S. (2006). Tanets yak zasib vykhovannia plastychnoi maisternosti [Dance as a Means of Educating Plasticity Skills]. Kyiv, 168 p. [in Ukrainian].

2. Masol, L.M. (2006). Zahalna mystetska osvita. Teoriia i praktyka: monohrafiia [General Artistic Education. Theory and Practice: Monograph]. Kyiv: Promin, 432 p. [in Ukrainian].

3. Mykhailychenko, O.V. (2004). Osnovyzahalnoi ta muzychnoi pedahohiky [Fundamentals of General and Musical Pedagogy]. Theory and History: Teaching Aid for Students of Music Specialties. Sumy: Nauka, 210 p. [in Ukrainian].

4. Oleksiuk, O.M. (2006). Muzychna pedahohika [Musical Pedagogy]. Teaching Aid, Kyiv: KNUKiM, 188 p. [in Ukrainian].

5. Otych, O.M. (2008). Mystetstvo rozvytku indyvidualnosti pedahoha. Istorychnyi $i$ metodolohichnyi aspekt: monohrafiia [The Art of the Development a Teacher's Individuality. Historical and Methodological Aspect: Monograph]. Chernivtsi: Zelena Bukovyna, 440 p. [in Ukrainian].

6. Padalka, H.M. (2008). Pedahohika. Teoriia $i$ metodyka vykladannia mystetskykh dystsyplin [Pedagogics. Theory and Methodology of Teaching Artistic Disciplines]. Kyiv: Osvita Ukrainy, 274 p. [in Ukrainian].

7. Rudnytska, O.P. (2005). Pedahohika: zahalna ta mystetska [Pedagogics: General and Artistic]. Ternopil: Navchalna Knyha, 284 p. [in Ukrainian].

8. Cherkasov, V.F. (2016). Teoriia i metodyka muzychnoi osvity [Theory and Methodology of Music Education]. Teaching Aid. The Series Alma Mater. Kyiv: Akademia Publishing House, 240 p. [in Ukrainian].

Стаття надійшла до редакції 21.02.2018

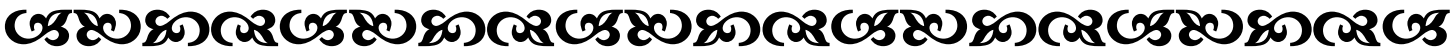

“Результатом освіченості людини є ї̈ здатність продовжувати навчатися”. Dжон Фъюї америқанський боілособ

"Жіхто не пожне мічної слави від будь-яқого поқлиқання, яқщо працю за иим поклиқанням не вважатиме за найсолодшу, більшу від самої слави втіху".

Тригорій Сқоворода український просвітитель-гуманіст, боілособб, поет, педагог

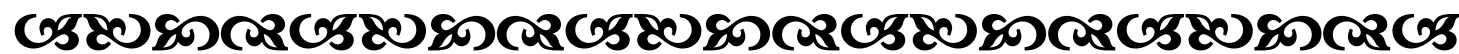

